\title{
VASÚTI HIDAKNÁL ALKALMAZOTT MONITORING-RENDSZEREK
}

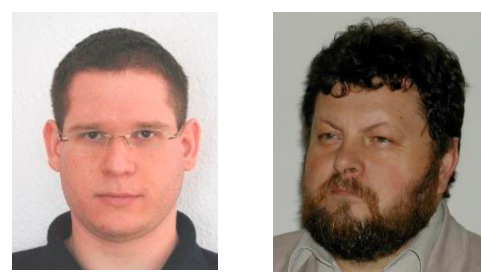

Erdei Balázs - Erdődi László Zoltán

A MÁV Zrt. hídállományának üzemeltetése során a korszerü felügyeleti rendszerek megjelenése és alkalmazása lehetövé tette a hídszerkezetek állapotváltozásának folyamatos nyomon követését. Üzemeltetői szempontból is egyre fontosabbá vált a szerkezetek pillanatnyi állapotának és az állapot alapján a várható élettartamának, teherbírásának minél pontosabb meghatározása. Cél, hogy a felügyelet során idöben megállapithatóak legyenek a romlási folyamatok, és hogy kellö időben tervezhetöek legyenek a szükséges beavatkozások.

Az alábbiakban a 2000-ben épült Nagyrákosi völgyhíd monitoring vizsgálatának eredményeit és tapasztalatait, valamint a 2016-ban, a 8. sz. föút Várpalota elkerülö szakaszán épült B2 és B4 jelü vasúti hidakon létesitett monitoringrendszert mutatjuk be, ami a fejlesztéseknek köszönhetöen már távfelügyeletként müködik.

Kulcsszavak: távfelügyelet, monitoring, állapotváltozás, romlási folyamat

\section{BEVEZETÉS}

A MÁV régóta alkalmaz felügyeleti, mai szóhasználattal monitoring rendszereket. Ezek kezdetben mechanikus, vagy hidraulikus müködésűek voltak. A beépített hidraulikus emelőkre szerelt manométer segítségével tudták 1930-tól figyelemmel kísérni a támaszerők változásait az első folytatólagos többtámaszú dunaföldvári Duna-hídon. Mára sokkal korszerübb berendezések figyelik és regisztrálják hídjaink állapotváltozását. A legújabb fejlesztés ezen a területen a távfelügyelet, aminek segítségével központi szerverre érkeznek a pillanatnyi állapotot nyomon követhető jelek, adott esetben elöre meghatározott küszöbértékek túllépése esetén vészjelzés.

\section{MONITORINGRENDSZEREK A NAGYRÁKOSI VÖLGYHÍDNÁL}

\subsection{A Nagyrákosi völgyhíd ismer- tetése}

A Zalalövő-Bajánsenye-oh. vasútvonal 3. zónájában az I. jelü völgyhíd a vasúti pálya szelvényezése szerint a 309+15 és a $323+15$ hm-szelvények között épült. A híd felszerkezete kétbordás, egycellás zárt szekrény keresztmetszetü feszített vasbeton gerenda. A feszített vasbeton szekrény nagy hajlítási merevsége következtében az alakváltozások (lehajlások) minimálisak, így a vasúti pálya átvezetésére különösen alkalmas. Statikai rendszerét tekintve három részből álló folytatólagos többtámaszú híd.

Az A jelü híd 704 m hosszú, 16 nyílású szerkezet. A híd tengelye egyenes.

Másik oldalon a C jelü híd hossza 614 m, 14 nyílású szerkezet. Ez a híd ívben fekszik.

A két hosszú híd között a dilatációs mozgások minimali- zálása érdekében egy rövid, kétnyílású híd épült. A hídszerkezeten létrejövő mozgások nagysága (beton zsugorodása és lassú alakváltozása okozta rövidülések, illetve a hőmérsékletváltozás miatti rövidülés/tágulás), valamint a sínszálak mozgásainak nagysága eltérő, ezért a mozgáskülönbségek lehetőségét biztosító síndilatációs berendezések épültek be a hídfök mögött, illetve a rövid (B jelü) hídszakasz elött és után.

A hosszú szakaszon alkalmazott fix megtámasztások a dilatációs hossz mértékét csökkentik oly módon, hogy a hosszú hídszakaszok középtáján két-két fix támasz felezi a dilatáló hosszat.

A felszerkezet alsó és felső lemezében egyenes kábelek vannak, melyeket a szakaszos előretolásos építési technológia miatt a zömvégeken horgonyoztak le. A bordákban a felszerkezet betolás utáni igénybevételeit követő íves kábelek helyezkednek el.

A hasznos terhek viselésére a szekrény belsejében bordánként két-két, a szekrény belsejében szabadon vezetett csúszókábel van. Az A és a C hídnál bordánként egy-egy kábelnél, a kábelek mindkét végén erőmérő cellákat építettek be, így a kábelekben lévő feszítőerő ellenőrizhető.

A hídtengely egyik oldalán, a teljes hídhosszon, minden egyes támaszon hosszirányban mozgó, keresztirányban fix, a másik oldalon minden támaszon, minden irányban mozgó sarukat építettek be. A hosszirányú vízszintes erőket a fix támaszokon lévő acélszerkezetű csapok veszik fel. A sarukat a német Maurer cég szállította, minden saru elmozdulás és reakcióerő mérésére alkalmas kivitelű.

\subsection{Telepített monitoring eszközök}

A völgyhíd egyedi jellege miatt a Vasúti Hídszabályzat IX. fejezetében elöírt vizsgálatokon, méréseken túlmenően a fenntartási és karbantartási munkák tervezéséhez többletvizsgálatokat és méréseket kell végezni, melyek kiegészítésére különböző monitoringrendszereket telepítettek a hídon. 
A völgyhíd fenntartási utasításában szerepelnek a szerkezet mérhetö paramétereinek elöre definiált határértékei is. Így a felügyelet során időben megállapítható a romlási folyamat, és a határértékek elérése előtt már tervezhetővé válnak a szükséges beavatkozások.

2000-ben a híd építése során, illetve a forgalomba helyezés elött a felszerkezetek hosszváltozásának és dilatációs mozgásainak mérésére, valamint a hőmérséklet eloszlásának mérésére, illetve 2002-tỏl a sín dilatációs mozgásainak és a sínhőmérsékletek mérésére telepített eszközök helyi adatgyüitőkhöz kapcsolódtak, az adatok mentése manuálisan történik. A szabadkábelek ellenörzését 1-1 kábel lehorgonyzásába beépített erőmérő hengerekkel a helyszínen alkalmanként leolvasással végeztük.

2016-ban a C jelü híd végében, 2017-ben a $B$ jelü híd mindkét végén lévő érzékelőket a rendszer korszerüsítésekor online adatgyüjtő rendszerhez kapcsoltuk, melyet kibővítettünk egy-egy keresztmetszetben elhelyezett négy szerkezet-, egy külső és egy belső levegőhőmérővel.

\subsection{A hőmérséklet eloszlásának mérése}

A hőmérséklet mérését az A jelű híd II. nyílása közepén telepített automatikus, helyi adatgyüitővel összekapcsolt érzékelőkkel végeztük. A hőmérők közül két-két darabot a vasbeton lemez, illetve borda belsejében, egy hőméröt a szekrénytartó belsejében, egyet pedig a szekrénytartó jobb (északi) oldalára kívülről helyeztünk el.

Az adatgyüjtő 2000. október 25-ei indulásától számítva 1813 napon keresztül (az első 5 évben) folyamatosan, 3 óránként, 2006-ban 133 és 2010-ben 107 napon keresztül működött, 2010. július 14-e óta nem rögzíti az adatokat.

A C jelü híd hídfójénél 2016. október 21-én telepített online mérőrendszer részeként az utolsó nyílás egy keresztmetszetének hömérsékleteloszlás-mérése a szerkezetben $10 \mathrm{~mm}$ átméröjü, $20 \mathrm{~cm}$ mély furatokban elhelyezett négy hömérő szenzorral, a belső levegö-hőmérséklet mérése a pályalemez alsó síkjához rögzített léghömérövel, míg a környezet hőmérséklete külső léghőmérővel történik. A hömérsékletadatok rögzítése jellemzően óránként történik.

\subsection{Hosszváltozás és dilatációs mozgások mérése}

A hídhosszakról „," mérés nem készült, csak a hídfők, valamint a hídvégek közötti távolságokat mérték meg. A hőmérséklet függvényében ezek a távolságok változnak, de közel azonos hőmérsékleten mérve, az idő múlásával a hídhosszcsökkenések lassulnak.

A hőmérsékleti adatok hiányában 2010 óta a szerkezet hömozgását nem lehet az elméleti hőmozgással összehasonlítani, és a hídszerkezetek hosszváltozását sem lehetett egyértelmúen $\left(15^{\circ} \mathrm{C}\right.$ léghőmérsékleten) meghatározni, ezért a hídszerkezetek hosszváltozását a téli időszakban mért leghidegebb hőmérséklethez tartozó dilatációs mozgásmérés mérési eredményeinek összehasonlításával végeztük a hömérséklet-különbségből számított hosszváltozással való korrigálás nélkül.

Az eredmények azt mutatják, hogy az első öt évben a prognosztizált és a mért adatok jól közelítenek egymáshoz. 10-15 év elteltével a hídhosszak csökkenése lelassult, a hídhosszak az elmúlt 10 évben kismértékben változtak.

A mérésböl nyert adatok alapján, a leghidegebb napokon mért adatokból megállapítható, hogy az idő múlásával szá- mított hídhossz-csökkenések lassulnak (1. ábra) és kisebbek, mint a fenntartási utasításban megadott, 25 évre prognosztizált hídhossz-csökkenések (a hídvégeknél mérhető távolságnövekmények) $125 \%$-a.

A sín és a híd dilatációs mozgásait összehasonlítva megállapítható, hogy a szerkezetek és sínek hőmozgása nem gátolt. A sín dilatációs mozgása a híd dilatációs mozgásával összhangban van (2. ábra). A mérések, valamint a szemrevételezéses vizsgálatok alapján az ágyazat nem torlódik egyik irányba sem.

\subsection{Szabadkábelek feszítőerő- változásának mérése}

A szabadkábelek ellenőrzését a kábelek lehorgonyzásába beépített erőmérő hengerek leolvasásával és az elöző mérési eredmények összehasonlításával végeztük a forgalomba helyezést megelőző próbaterhelés előtt és után (2000-ben), valamint 2003-ban, 2011-ben, 2014-ben és 2016-ban.

A negyedik, 2011-es mérés után az alábbi megállapítások születtek:

- A feszítéskori (ledugózás utáni) feszítőerők a próbaterhelés után az $\mathrm{A}$ jelű hídnál növekedtek, a $\mathrm{C}$ jelủ hídnál pedig csökkentek. Ezek a változások azzal magyarázhatóak, hogy a próbaterhelés során bekövetkezett mozgások fölszabadították a kábeltöréseknél esetleg fellépő súrlódásokat, és a feszítőábelek „beálltak”.

- A problémát kissé bonyolítja az a körülmény, hogy a ledugózáskor a vasúti felépítmény még nem volt a hídon, bár ennek többlethatása az erőmérő celláknál alig volt érzékelhetö.

- Három év elteltével az A jelü hídnál van némi csökkenés, a $C$ jelü hídnál pedig csekély növekedés.

- A 2011. március 24-i mérés során ( 10 év után) négy cellánál csökkenés mutatható ki.

1. ábra: A Nagyrákosi völgyhíd dilatációs mozgásmérési eredményei

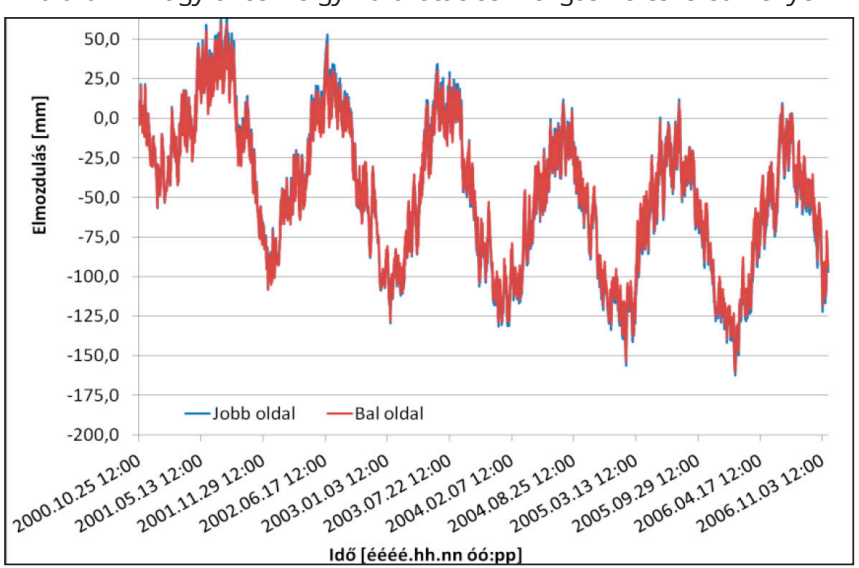

2. ábra: A Nagyrákosi völgyhíd sín- és híddilatációs mozgásainak összehasonlítása

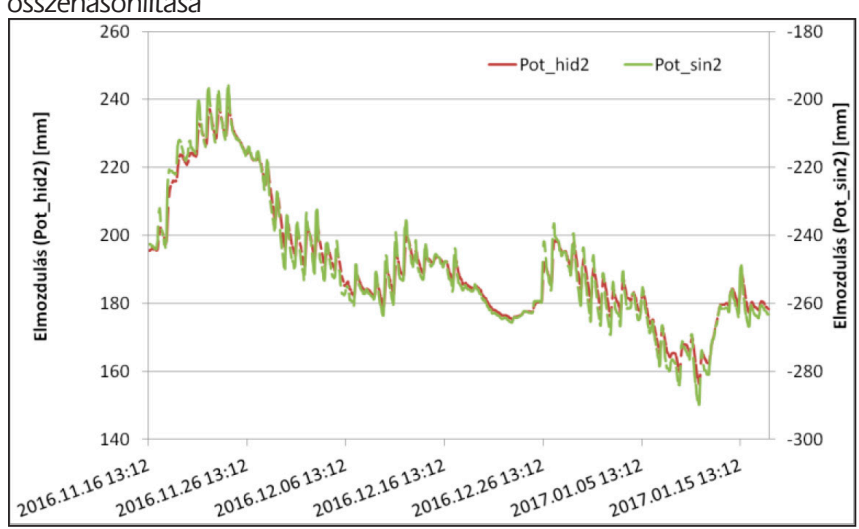




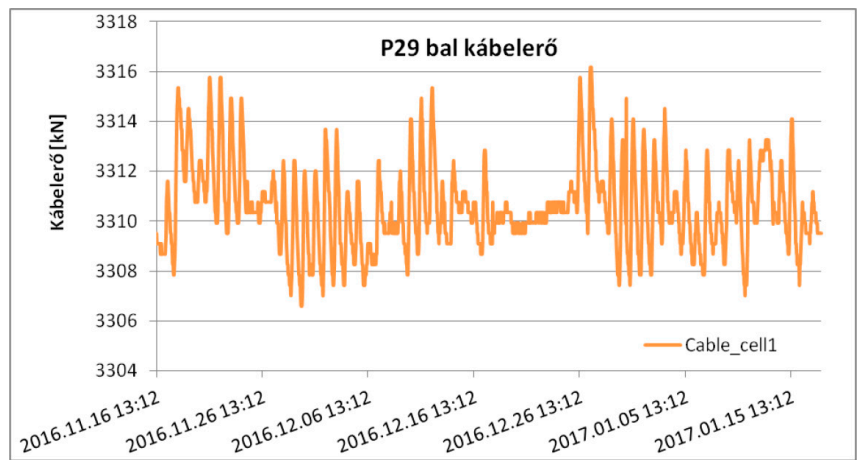

3. ábra: Feszítőerő-változás a Nagyrákosi völgyhíd szabadkábelében

- A számításoknál a próbaterhelés utáni állapotot vették alapul.

- A mérések alapján nem megismerhetőek az évszakváltás okozta különbségek.

A további mérések alapján megállapítható, hogy a szabadkábelekben lévő feszítőerő gyakorlatilag nem változott. A feszítőkábelek relaxációjából, a beton zsugorodásából és lassú alakváltozásából összeadódó, a statikai számításban T = $\infty$ időpontban figyelembe vett $10 \%$-os feszítőerö-csökkenés egyik kábelnél sem mutatható ki.

A C jelü hídnál 2016. október 21-én telepített mérörendszer által a beépített cellákon való rendszeres mérések hasznos információkat szolgáltatnak a feszítőerők időbeni változásának meghatározásához. Az erőmérő hengerekhez kapcsolt adatgyüjtő jellemzően óránként rögzíti az adatokat (3. ábra).

Az online adatgyüjtő rendszer üzembe helyezése után tartott terheléses vizsgálat során, az adatgyüjtő mérési frekvenciáját $10 \mathrm{~Hz}$-es mintavételezésre átállítva, mértük a hasznos teher hatására keletkező feszítőerő-változást (4. ábra).

A híd végén a pálya $R=2300$ m sugarú jobb ívben halad. A terheléses vizsgálatkor az ív külső oldalán lévő bal oldali kábel két végén mérhető feszültségváltozás nem volt. A hasznos teherviselésében főként az ív belső oldalán lévő, jobb oldali kábel játszott szerepet. A kábelen átlagosan 3-4 kN feszítőerő-változás volt mérhető, ami csupán $1 \%$-nyi változást jelent.

A feszítőerő-változást hosszabb távon vizsgálva, azt a szerkezet dilatációs mozgásával összehasonlítva a következőket tapasztaltuk: A szabadkábelek feszítőerőinek változásai a híd dilatációs mozgásával szintén összhangban vannak, valamint a hídhossz változásának következtében lényegesen nagyobb feszítőerö-változás lép fel, mint jármüáthaladás során, mind a négy mért ponton.

4. ábra: A hasznos teher hatására keletkező feszítőerő-változás

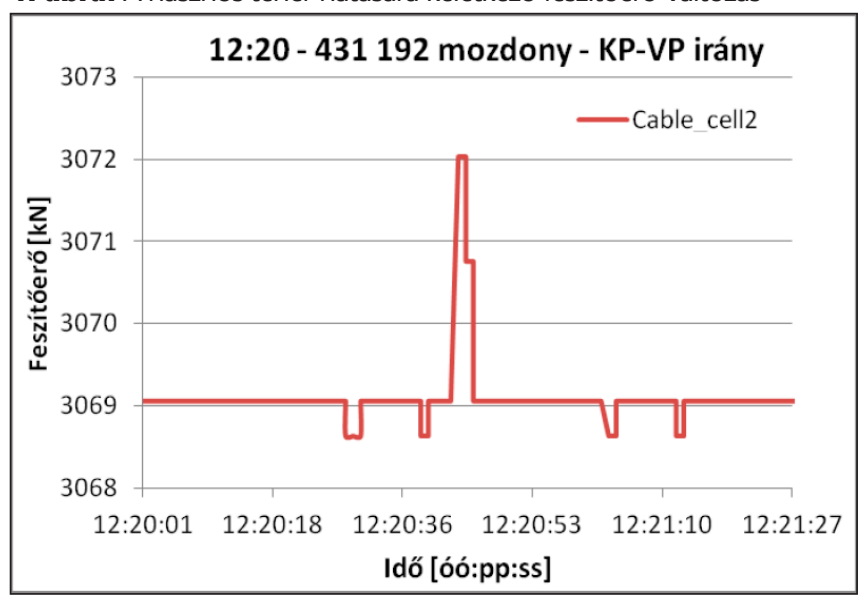

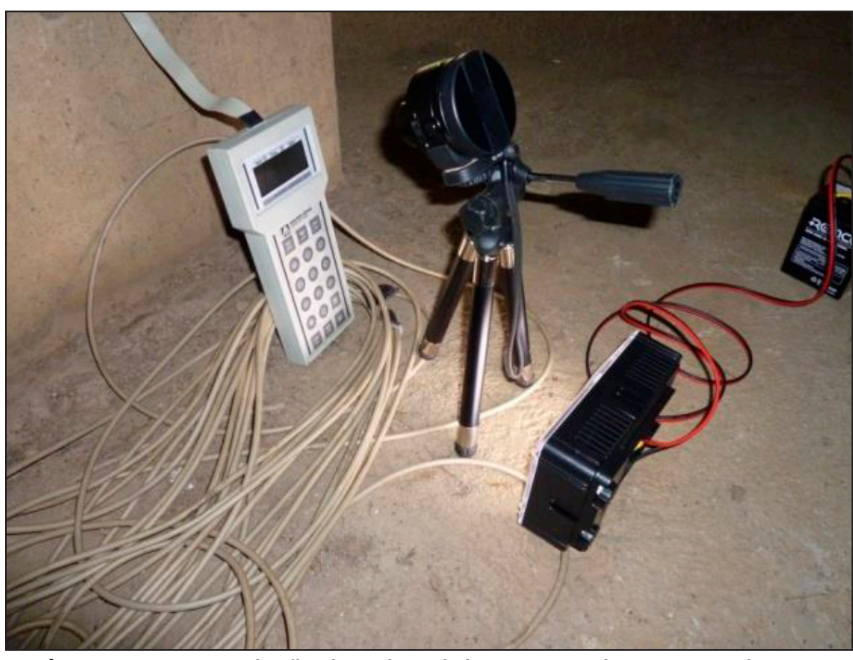

5. ábra: Saru reakcióerő-változás mérése a Nagyrákosi völgyhídon

\subsection{A saruerő változásának mérése}

A hídsaruk ellenőrzését a beépített reakcióerő-mérők leolvasásával és az előző mérési eredmények összehasonlításával végeztük a forgalomba helyezést megelőző próbaterheléskor (2000ben), valamint 2001-ben, 2005-ben, 2010-ben és 2014-ben.

A reakcióerők értéke az alépítmények függőleges mozgásának függvénye. A változások mértéke mutatja a „,0”, illetve előző mérésekhez képest az alépítmények süllyedésviszonyait. A híd felszerkezetére nem káros, egyenletes alépítménysüllyedések elméletileg nem okozhatnak jelentős reakcióerőváltozásokat.

2016-ban az online adatgyüjtő rendszer üzembe helyezése után tartott terheléses vizsgálat során, vonatáthaladáskor a végponti hídfő jobb saru reakcióerő-változását mértük a meglevő leolvasó egység megfigyelésével (digitális képi rögzítés, terhelt és terheletlen állapotban) (5. ábra).

Az elöző mérések során a reakcióerök mérése a sarukba beépített mérőberendezés segítségével csak a szerkezet önsúlyára (terheletlen állapotban) történt. A mérési adatokkal kapcsolatban az alábbi megállapításokat tettük:

- A vonatáthaladások után mért értékek azonnal nem álltak vissza az áthaladás előtt mért értékre, több perc elteltével kezdett csak csökkenni a kijelzett saruerő. A két V43 mozdony áthaladása között eltelt $\sim 20$ perc után is maradt 30 kN különbség a mért értékek között.

- A V43 mozdonyok alatt mért saruerő-változás 120 és 160 kN között mozgott.

- A fent leírtak alapján, valamint, hogy az egy keresztmetszetben lévő két saru reakcióerőinek egyidejü leolvasása nem megoldott, a mérési bizonytalanság akár több mint 50 $\mathrm{kN}$ is lehet.

Cél, hogy a C jelü híd utolsó alátámasztásain lévő sarukat bevonjuk a 2016-ban telepített online adatgyüjtő rendszerbe, és a rendszeres mérésekkel meghatározzuk a reakcióerők időbeni változását, ami csökkentheti az előző mérések bizonytalanságát is, így a reakcióerő-mérések valóban az alépítmények geodéziai mérésének kontrolljává válhatnak.

\section{MONITORINGRENDSZEREK A VÁRPALOTÁT ELKERÜLŐ ÚT VASÚTI HIIDJAINÁL}

A NIF Zrt. beruházásában és az SDD Konzorcium Várpalota kivitelezésében épültek meg a 8. sz., Várpalota déli elkerülő fớt vasúti mütárgyai az alábbi szelvényekben: 


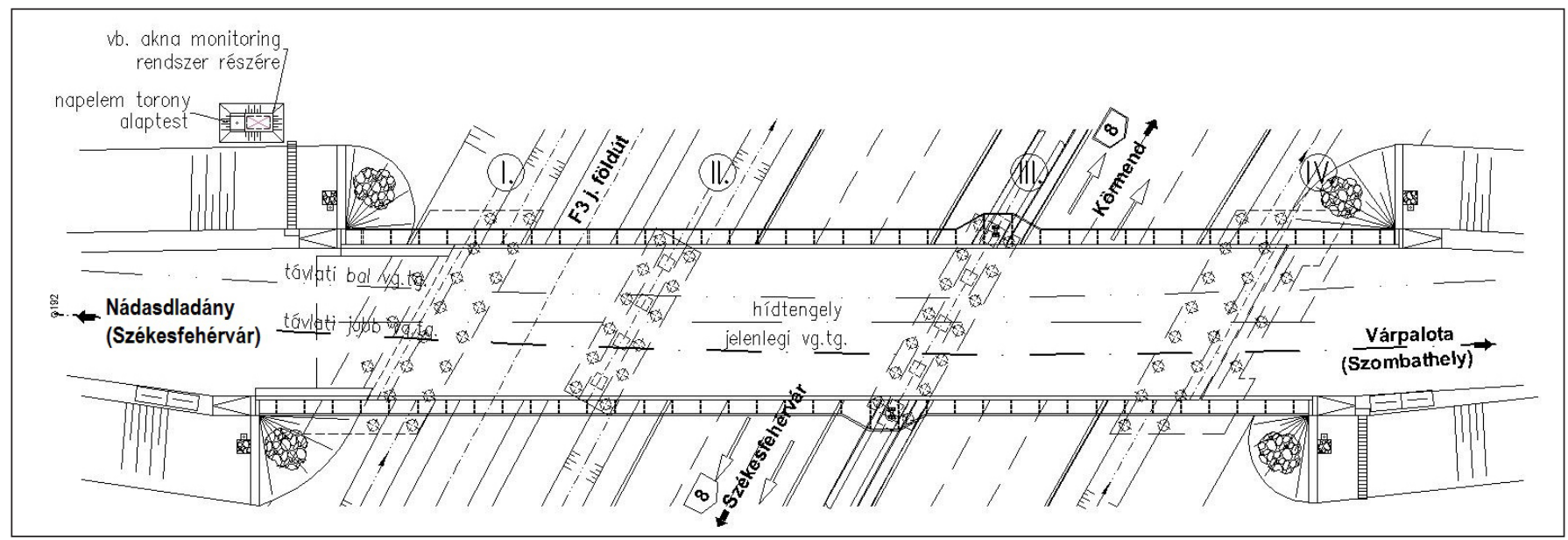

6. ábra: A B-2. jelű híd alaprajzi elrendezése

B2 jelü vasúti híd a 8. sz. fớt 25+096,27 km-szelvényében és a Székesfehérvár-Szombathely vasútvonal 192+59,65 hm-szelvényében;

B4 jelü vasúti híd a 8 . sz. fooút 29+349,89 km-szelvényben és a Székesfehérvár-Szombathely vasútvonal 240+94,97 hm tervezett szelvényében.

A hidak a 30,71 m koronaszélességü 8. sz. föút felett vezetik át a vasutat.

\subsection{A B2 jelü híd adatai:}

támaszköz: $15,00+22,00+20,50 \mathrm{~m}$

szerkezeti hossz: $58,60 \mathrm{~m}$

a felszerkezet szélessége: $13,18 \mathrm{~m}$

a keresztezési szög: $60^{\circ}$

A hídszerkezet a végleges állapotát két ütemben fogja elnyerni.

$\mathrm{Az}$ első ütemben (a híd építésekor) a hídon egy vágány épült, ami későbbi vasútfejlesztés során bővül újabb vágánynyal. A hídszerkezet a távlati pályakialakításhoz igazodóan épült meg, $\mathrm{R}=800 \mathrm{~m}$ sugarú ívben (6. ábra).

A híd felszerkezete háromnyílású, folytatólagos négytámaszú, acél tartóbetétekkel együttdolgozó monolit vasbeton lemez, ágyazatátvezetéssel, keresztmetszete a 7. ábrán látható.

Az I. jelü hídföre fix, a közbenső támaszokra és a IV. jelü hídfőre két irányban mozgó sarukat építettek be.

A hídszerkezetek hídfői és közbenső támaszai cölöpalapozással készültek. A mútárgy helyén a vasúti töltést 4,8 m magas háttöltéssel szélesítették, aminek következtében a várható süllyedés $7 \mathrm{~cm}$ volt.

\subsection{A B4 jelü híd adatai}

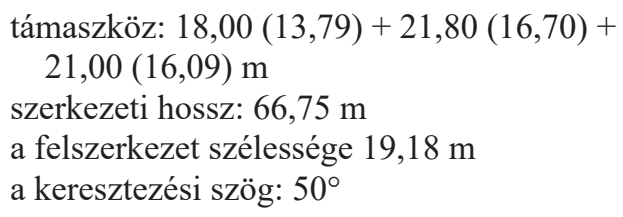

A hídszerkezet a végleges állapotát két ütemben fogja elnyerni.

Az első ütemben a hídon két vágány épül haránt irányban, ez későbbi vágánykorrekció során újabb vágánnyal bővül $(8$. ábra). A hídszerkezet a távlati pályakialakításhoz igazodóan épült meg (9. ábra).

A híd felszerkezete háromnyílású, folytatólagos négytámaszú, acél tartóbetétekkel együttdolgozó monolit vasbeton

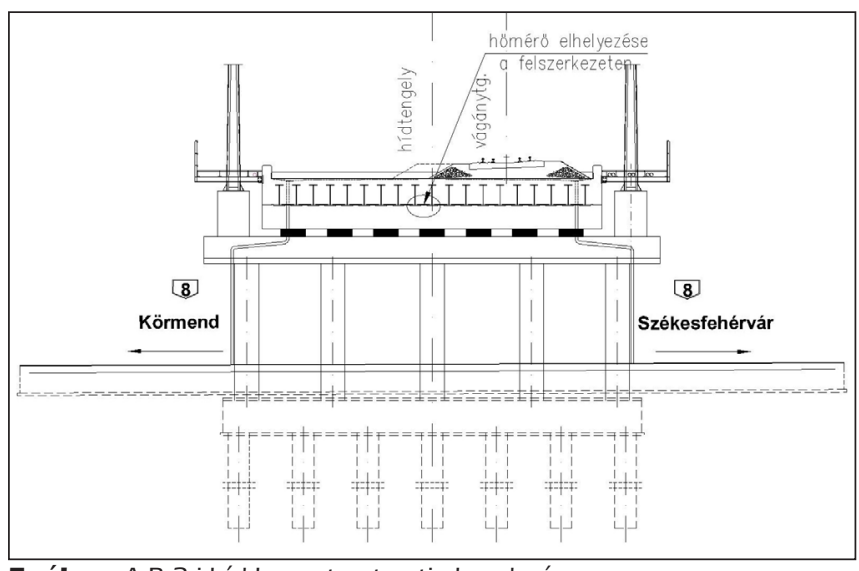

7. ábra: A B-2 j híd keresztmetszeti elrendezése

lemez ágyazatátvezetéssel. Az A jelű hídföre fix, a közbenső támaszokra és a D jelű hídföre két irányban mozgó sarukat építettek be.

A hidakon a vasúti pályatest helyzete a vasútvonal korszerüsítése során változik, ezért a felszerkezet egybe betonozott acél tartóbetétes vasbeton lemez, hogy a felszerkezet minden pontja alkalmas legyen a vasúti pálya terheinek korlátozás nélküli viselésére.

A hidak tervezésekor azt vélelmeztük, hogy a nagy ferdeségü, többtámaszú monolit szerkezetek az alépítmény mozgására fokozottan érzékenyek, ezért ennek nyomon követése céljából kértük a szerkezet támaszmozgásának a figyelését, amit közvetetten a sarukon átadódó függőleges reakcióerőváltozásból láttunk követhetőnek, ugyanis a reakcióerő-változás már minimális mozgások esetén is jelez, és jól mérhető, nyomon követhető. Ezért olyan Mageba gyártmányú sarukat építtettünk be a hídszerkezet alá, amelyek alkalmasak a sarureakció mérésére. Az SDD Konzorcium alvállalkozójaként a Metalelektro Méréstechnika Kft. készítette el a monitoringrendszerhez az eszközök telepítési tervét. Ennek alapján telepítettek saruerőmérő, hőmérsékletmérö és a rendszer müködésének távmenedzselését biztosító berendezéseket. A mérörendszer elvi kialakítása az 10. ábrán látható.

A saruerő mérése céljából hidanként 8-8 db nyomásérzékelővel szerelt saruk elhelyezését a B2 hídnál a 11. ábra, míg a $\mathrm{B} 4$ hídnál a 12. ábra, a beépített méröcellás sarut a 13. ábra mutatja.

A saruk jeleinek fogadása, rögzítése és elküldése a MÁV szerverére óránként, internetes kapcsolattal történik. A hőmérséklet mérésére hidanként egy-egy szerkezeti hőmérőt telepítettek a felszerkezetbe a 14. ábrán látható módon.

A hőmérsékletmérés a szerkezetben $20 \mathrm{~cm}$ mély $10 \mathrm{~mm}$-es furatban történik, a hőmérőt dübellel rögzítették. A szolgáltatott adatot, a szerkezet hőmérsékletét ( ${ }^{\circ} \mathrm{C}$-ban) rögzítik. A 


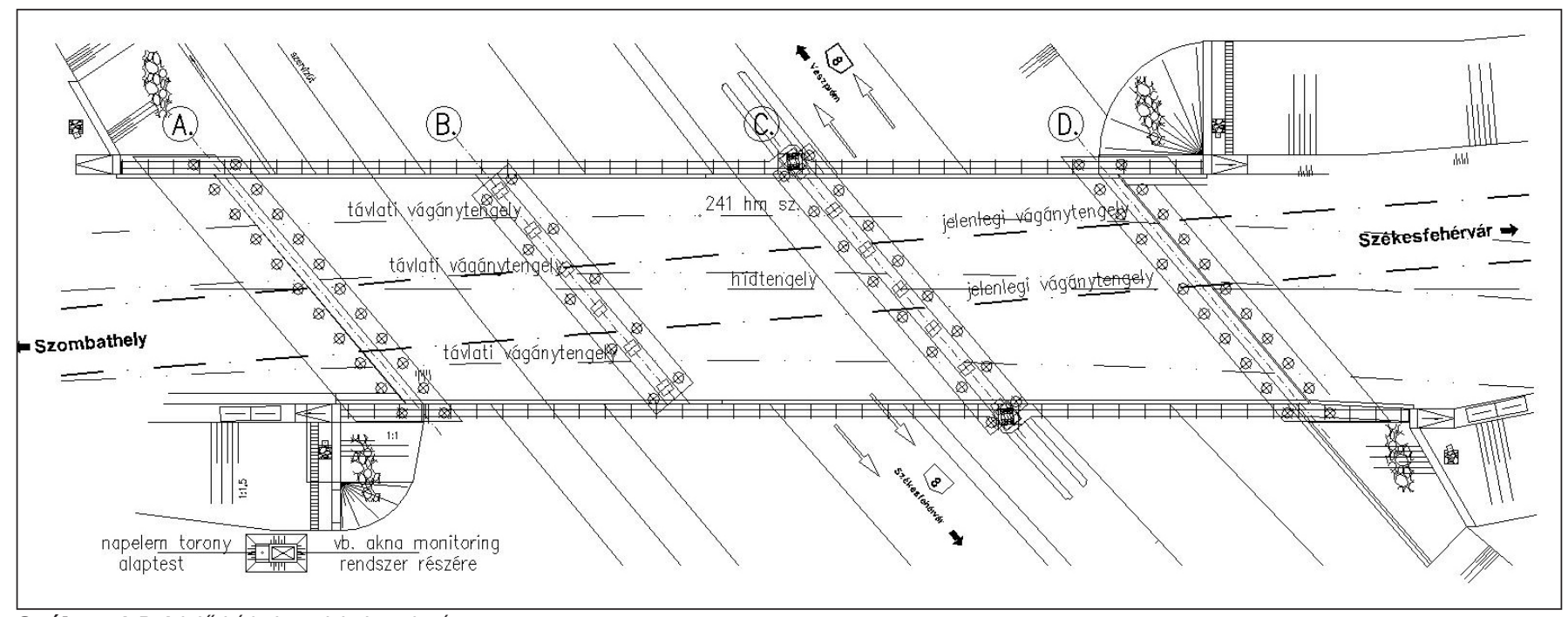

8. ábra: A B-4 jelű híd alaprajzi elrendezése

monitoringrendszer-üzemelés hidankénti $1700 \mathrm{Wh} /$ hét energiaigényét, $3 \mathrm{~m}^{2}$ felületü napelem torony biztosítja (15. ábra). Az akkumulátorokat, az adatgyüjtő és -továbbító rendszert közvetlenül a torony mellé épített monolit vasbeton aknába telepítették (16. ábra).

Az aknákat a B2-es híd mellett a Székesfehérvár felőli hídfő bal oldali rézsülábánál, míg a B4-es hídnál a Szombathely felőli hídfö szintén bal oldali rézsülábánál helyezték el a rézsủlábtól 1,0 m távolságra, a terepszintből 0,5 m-re kiemelve, a külső oldalfala mentén távolodva eső rézsűs földmű kialakítással, hogy védjék a felszíni vizektől.

A mérőrendszert az internetes GSM kapcsolaton kívül egy biztonsági belső akkumulátorral GSM távjelzővel is ellátták annak érdekében, hogy a napelemes akkumulátorok feszültségkiesése esetén is tudjon riasztást küldeni. Tájékoztat a rendszer hibáiról, áramkimaradásról, továbbá szabotázs vagy rongálás esetén is. A MÁV Zrt. Szolgáltató Központ IT szerverén futó alkalmazás segíti a telepített müszerek müködőképességének távoli menedzselését úgy, hogy SMS-t küld a GSM távjelzőnek,

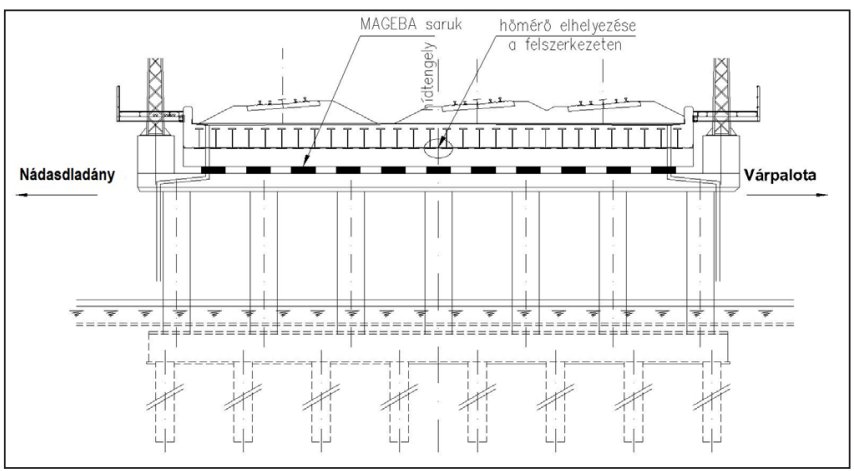

9. ábra: A B-4 jelú híd keresztmetszeti elrendezése

amely felébreszti az adatgyüjtő rendszert a készenléti állapotból. Interneten keresztül hozzáférést biztosít az adatgyüjtőhöz. A mérési adatokat a berendezés a helyszínen tárolja, ezeket a szerver is lekérdezi és eltárolja. A következő SMS-sel a mérőrendszer ismét alvó állapotba állítható. Az adatgyüjtő paraméterei távolról is állíthatók, működőképessége ellenőriz-

10. ábra: A mérőrendszer elvi kialakítása

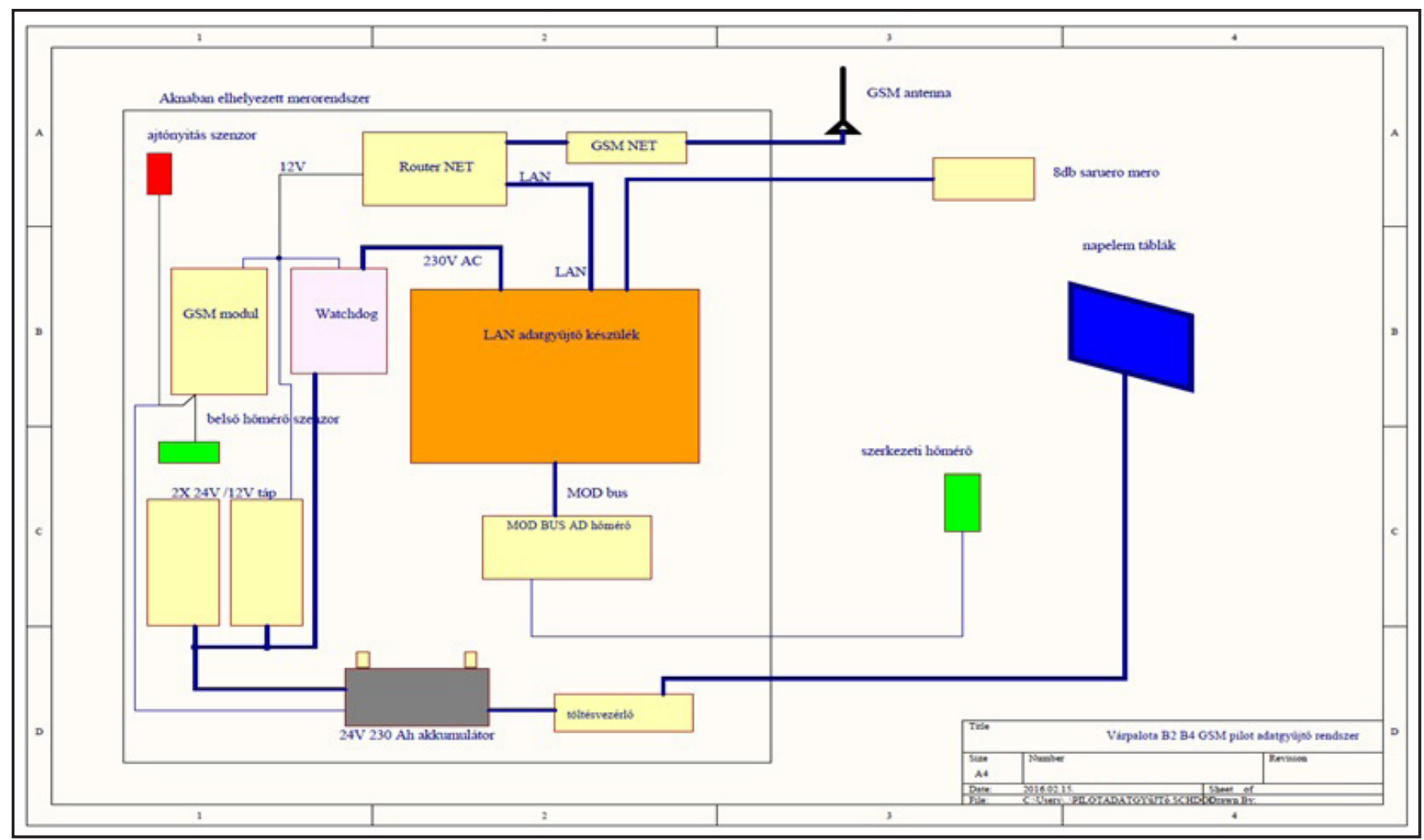




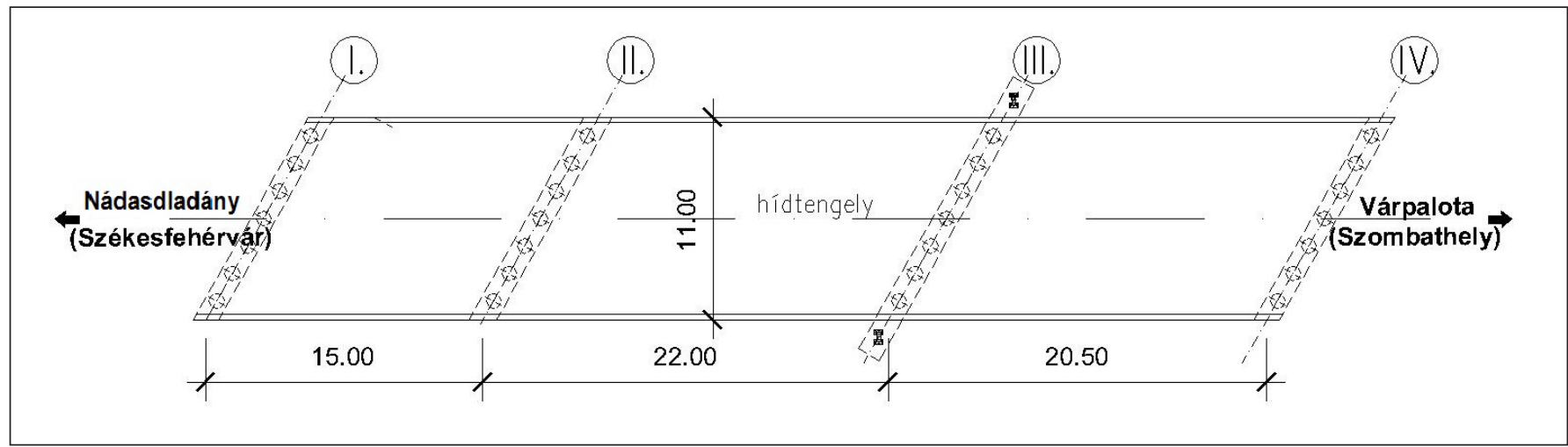

11. ábra: A mért saruk elrendezése a B-2. jelű hídnál

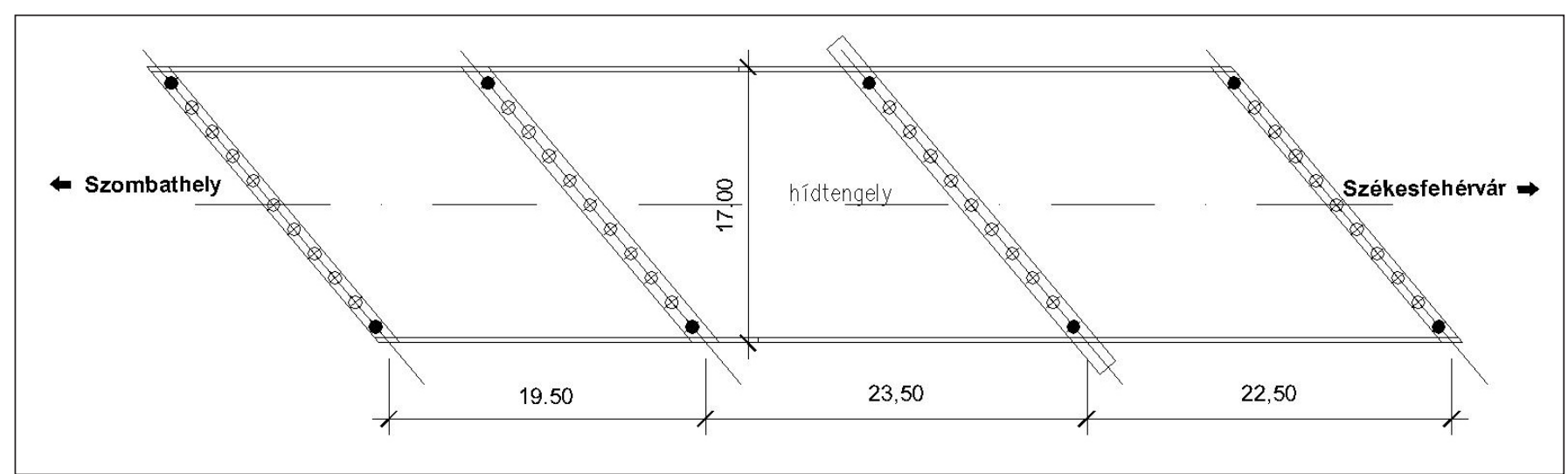

12. ábra: $A$ mért saruk elrendezése a $B-4$ jelű hídnál

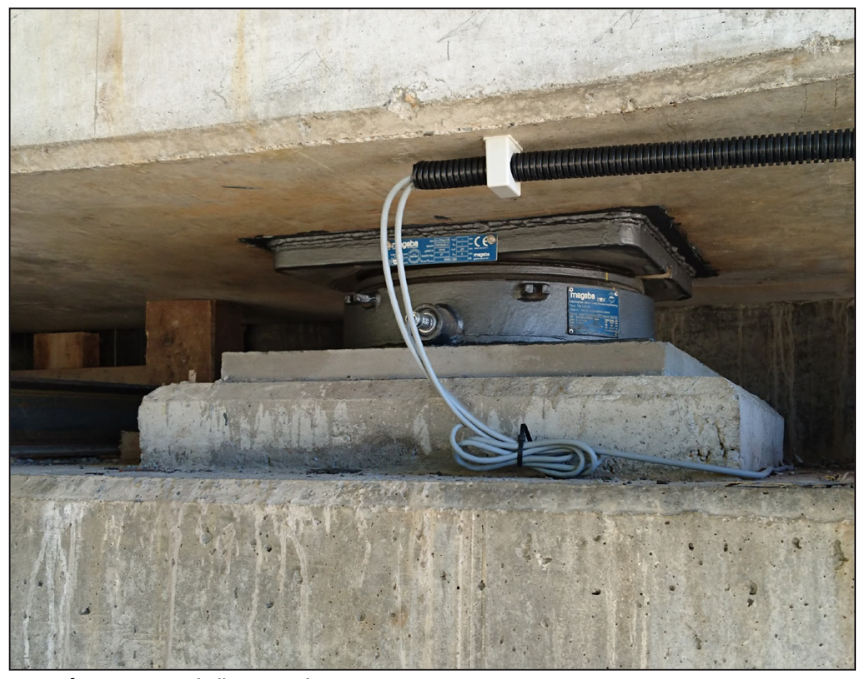

13. ábra: A mérősaru képe

hető, az SD kártyáról az adatok közvetlenül is letölthetők. A mérőelemek vezetékeit a mérőelemektől a híd hosszában futó kábelezésig gégecsőben a betonszerkezethez rögzítették. A híd hosszában a vezetékek KPE védőcsőben futnak, mindkét hídnál a vasúti szelvényezés szerint baloldalon, a járórács alatt.

Az egyes mérőelemek jelfeldolgozása, digitalizálása, az adatok rögzítése és továbbítása az aknában, zárt szekrényben elhelyezett mérő adatgyüjtő rendszerben történik. Ide futnak be a napelemek kábelei is, és itt helyezték el a töltésvezérlőt és az akkumulátort is.

A terepi mérö-, jelfeldolgozó eszközök a Szombathelyi Területi Igazgatóság üzemeltetési körébe kerültek.

A berendezések felügyeletét a hidász szakasz, karbantartását és a mérési eredmények kiértékelését a MÁV KFV Kft. végzi.

A tapasztalat alapján meghatározott értesítésre, riasztásra a szoftverben definiáltan kerül sor.

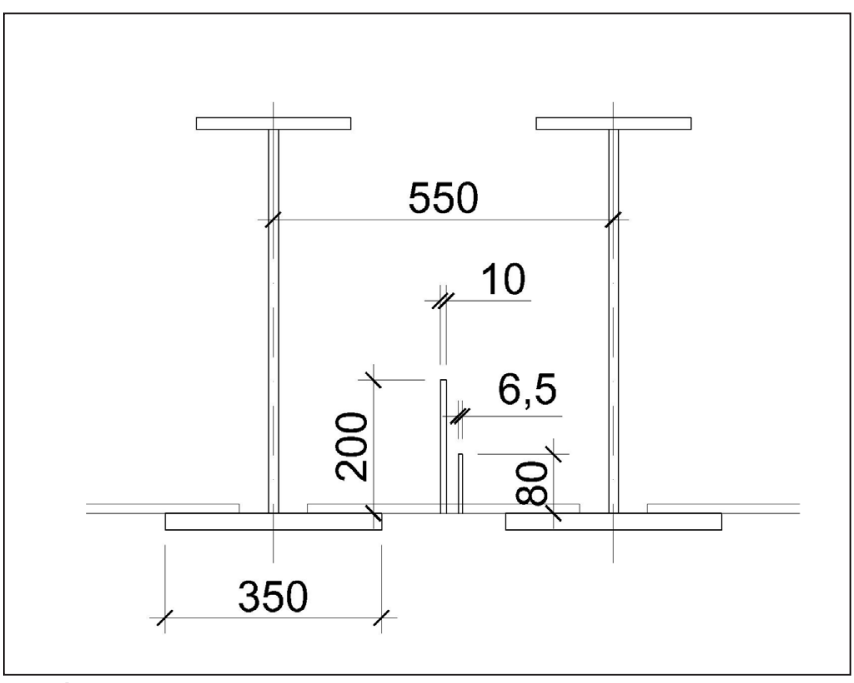

14. ábra: Hőmérő elhelyezése a felszerkezetben

\section{4.ÖSSZEFOGLALÁS}

A monitoring-rendszerek elvárt élettartama több mint 15 év. A Nagyrákosi völgyhíd vizsgálatai során szerzett tapasztalatok alapján a telepített monitoring eszközök megfelelő karbantartás mellett megbízhatóan, az elvárt pontossággal képesek müködni.

Ezeket a régi rendszereket, valamint az újonnan telepített rendszereket is bővíteni, korszerüsíteni lehet az új igényeknek megfelelöen.

\section{HIVATKOZÁSOK}

Wellner P. - Mihalek T. (2000), „A magyar-szlovén vasútvonal völgyhídjai (2. rész) A hídszerkezet általános ismertetése”, VASBETONÉPÍTÉS 2000/1, pp. 20-25

Vörös J. (2001). „A magyar szlovén vasútvonal völgyhídjai (6. rész) A hídszerkezetek próbaterhelése", VASBETONÉPÍTÉS 2001/1, pp. 15-23 


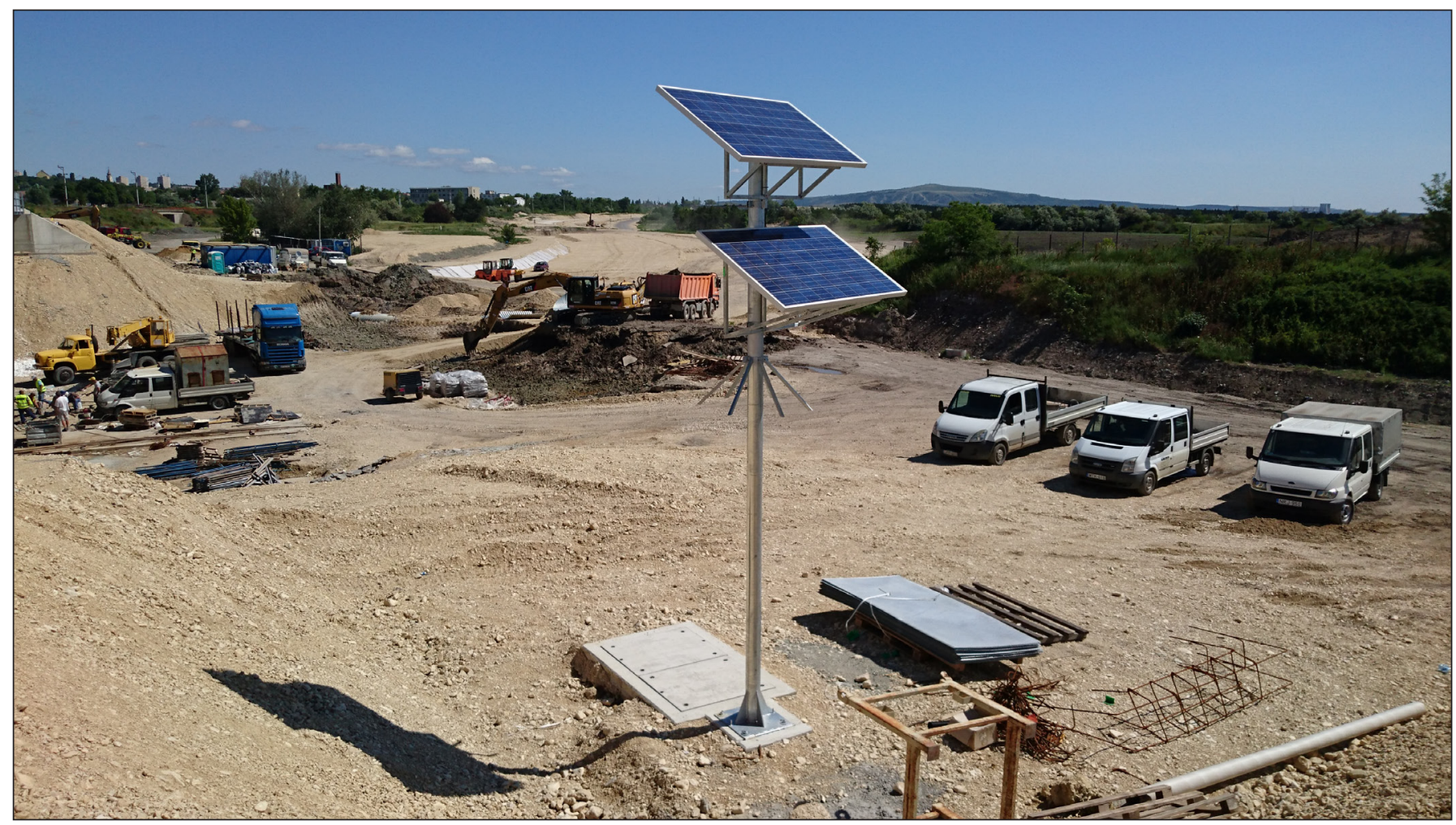

15. ábra: Az üzemeltetést kiszolgáló napelemek

Erdődi L. Z. (2018), „Monitoring rendszerek a Várpalotát elkerülő út vasúti hídjainál Vasúti hidak a MÁV Zrt. Szombathelyi Igazgatóság és a GYSEV ZRt. területén" (Vasúti Hidak Alapítvány Szombathely 2018) Könyvsorozat 6. kötet Vasúti hidaknál alkalmazott monitoring rendszerek c. fejezet pp. $431-438$

Metalelektro Kft. által készített dokumentáció 2000. MÁV Zrt. híd tervtár A hidak nyilvántartási tervei MÁV Zrt. híd tervtár

Erdei Balázs hidászmérnök 2009-ben diplomázott a Budapesti Műszaki és Gazdaságtudományi Egyetem Építőmérnöki Karán Híd és műtárgy szakirányon. 2009 júniusától dolgozik a MÁV Központi Felépítményvizsgáló Kft.-nél, ahol 2013 szeptemberétől csoportvezetö. 2014-ben a Pannon Egyetemen korrózióvédelmi szakmérnöki diplomát szerzett. Meglevő hidak időszakos és rendkívüli vizsgálatával, hidak felújításánál, karbantartásánál végzett vizsgálatokkal, valamint forgalomba helyezés előtti hídvizsgálatokkal, próbaterhelésekkel foglalkozik. 2018 augusztusától a MAV Központi Felépítményvizsgáló Kft. osztályvezetője.

Erdődi László Zoltán hidász mérnök. A győri KTMF-án hídépitési és fenntartási üzemmérnöki, a BME Építőmérnöki Karon okleveles szerkezetépítő mérnöki, majd a BME Közlekedésmérnöki Karon közlekedési manager gazdasági mérnök képesítést szerezett. 1978-tól a MÁV-nál dolgozik a hidász művezető beosztástól a hidász fóépítésvezető, területi hídszakértő, osztályvezető, jelenleg müszaki szaktanácsadó munkakörökben. A MÁV korszerủ hídgazdálkodását segítő rendszer, a MÁV HGR életre hívásának, és a hidakon alkalmazott monitoring rendszerek üzemeltetésének, fejlesztésének elkötelezett híve.

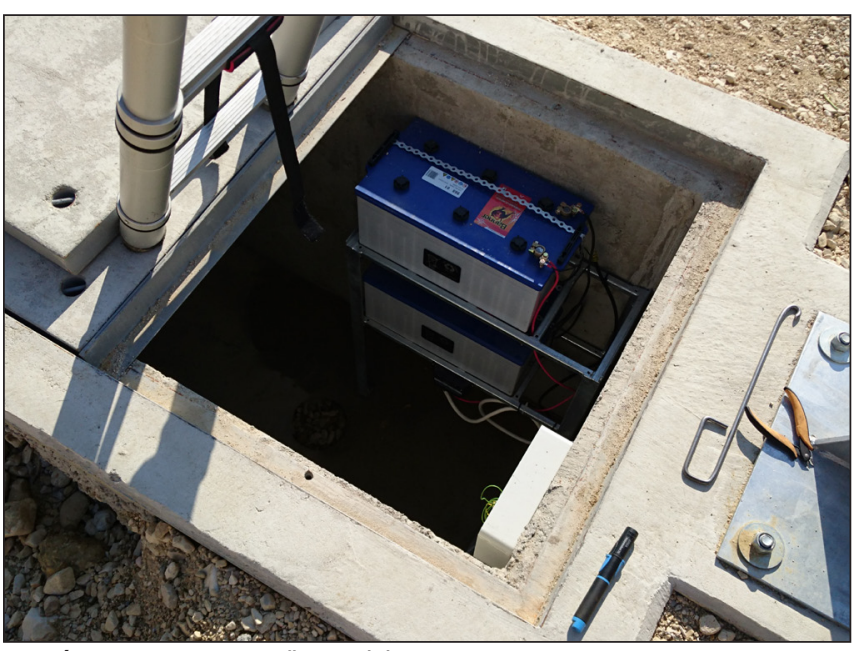

16. ábra: Az akna belsőkialakítása

\section{MONITORING SYSTEMS APPLICABLE AT RAILWAY BRIDGES}

\section{Balázs Erdei - László Zoltán Erdődi}

In the course of the operation of MÁV Co's bridge stock the appearance and application of modern inspection systems enabled the continuous tracking of the bridge structures' change of state. The more precise determination of the momentary state and on the base of the state its life expectancy and bearing capacity became more and more important also from operator's point of view. The aim is that in the course of the inspection the deterioration processes could be determined in time and the necessary interventions could be planned in appropriate time. 